\title{
A destruição, por queimadura, de grande parte dos cabelos da mulher, é lesão corporal ?
}

A. Almeida Júnior

\section{CONSULTA}

Submetida à aplicação elétrica usual, para “ondulação permanente", num "Instituto de Beleza", uma senhora sofre destruição, por queimadura, de quase todos os cabelos. Dada queixa e efetuado, no Serviço Médico-Legal, o exame de corpo de delito, o promotor público denuncia o cabeleireiro como incurso no art. 306 da Consolidação das Leis Penais (lesão corporal culposa).

Pergunta-se: a destruição, por queimadura, de grande parte dos cabelos de uma senhora (sem ofensa ao couro cabeludo) constitúi lesão corporal, no sentido legal da expressão?

\section{PARECER}

1 - Anexos da pele, formados, como o resto do organismo, por células que nascem, crescem e morrem, os cabelos fazem parte integrante do corpo humano, tanto quanto as unhas e os dentes. Biológicamente, cada fio de cabelo é um órgão (Pellegrini). Todavia, dados, de uma parte, o alcance jurídico da expressão “órgão", e, de outra, o valor mínimo de cada fio isolado, só merece tal classificação, em Medicina forense, a cabeleira no seu conjunto. 
2 - Qual o prejuizo trazido pela destruição de grande parte dos cabelos de uma mulher? Não houve dôr (como aconteceria se a perda tivesse ocorrido mediante arrancamento). Não se tratando de Sansão, cuja energia estava na cabeleira, não sobreveĩo diminuição da força física da vítima.

Mas houve dano estético.

3. - $\mathrm{O}$ valor estético da cabeleira feminina é celebrado desde SALomão: "os teus cabelos são como o rebanho das cabras que repousam nos flancos do monte Gilead. " (Cântico dos cantos, $I V, 1)$. Cirano de Bergerac tomou por fanal a coma loira de Roxana: "j’ai pris pour clarté ta chevelure" O herói de Educação Sentimental, de Flaubert, encontrando, depois de muitos anos de separação, a dama de seus pensamentos, sente, ao vêr-lhe os cabelos já brancos, "um choque em pleno coração" E, entre nós, no tempo das tranças, os moços diziam de cór um belo soneto, "O rouxinol de tranças”, de Frota Pessôa.

4. - Depois da grande guerra, o prestígio da cabeleira feminina entrou em colápso: vieram os cabelos "à la garçonne" Mas "esta legítima adoração" (profetizava Marañon, em 1929) "voltará” E voltou. A cabeleira da mulher é, de novo, nas mãos dos penteadores atuais, um material plástico para as mais imprevistas creações da arte; e a senhora que perdesse êsse encanto (mesmo por alguns mêses), se sentiria gravemente infeliz!

5. - Ora, a lei penal protege também contra o dano estético, tanto que inclúi, entre as lesões corporais, as que produzam unicamente "deformidade" De fato, o dano estético do corpo pode prejudicar o valor "social" do indivíduo, e até mesmo, através da criação de um "complexo de inferioridade", reduzir-lhe a eficiência psicológica. Nem é de 
extranhar que venha a ser causa (oculta ou manifesta) de sério desajustamento conjugal.

6. - Mas (dir-se-á) os cabelos crescerão de novo; dentro de dois ou três meses, serão o que eram antes. De acordo. A lei, entretanto, não exige que a lesão seja permanente para que se torne punível: a equimose, que dura duas ou três semanas, a dôr, que desaparece ao fim de alguns minutos, representam, muitas vezes, a consequência única do trauma. Nem por isso deixa de haver lesão corporal.

7. - Se a perda dos cabelos resultou de dolo do agente, não se tratará, por certo, de deformidade, desde que se possa prognosticar (ou verificar, posteriormente, em exame de sanidade) a desaparição do dano estético. Porque se fôr perda definitiva, a deformidade permanece (segundo ensina von Liszt), ainda que o defeito possa ser disfarçado com o uso de uma cabeleira postiça.

8. - Havendo dolo, não será tão pouco (crêmos nós) lesão grave do parágrafo único do art. 304, visto não ocorrer "incômodo de saude" Ficar-se-á no art. 303, que acolhe indistintamente todas as lesões corporais excluidas dos artigos seguintes, mesmo as que, como no caso em apreço, não produzam dôr nem derramamento de sangue. (Em face dos termos inequívocos da lei - "produzindo dôr ou alguma lesão no corpo" - o elemento dôr não é essencial para caracterizar a ofensa física do art. 303.)

9. - Poderá ser lesão culposa, do art. 306 da Consolidação das Leis Penais. Nesta época em que os "Institutos de Beleza" vivem abarrotados de clientes do belo sexo e os "técnicos" brotam do chão, como cogumelos, a imprudência, a negligência ou a imperícia dos cabeleireiros têm sido muitas vezes responsabilizadas, no extrangeiro e aqui, por lesões de maior ou menor gravidade: queimadura do cabelo e do 
couro cabeludo, devida a uso de material de celuloide (seis casos de Howard Fox); avermelhamento dos cabelos por excesso de temperatura, por demora do tempo de aplicação ou por aplicações demasiado frequentes (observações norte-americanas, casos de São Paulo); produção de manchas na cabeleira, em virtude de reaçốes químicas provocadas pelo calôr na tinta artificial (diversos casos de Londres e dos Estados Unidos). Se admitirmos que a mulher "a le devoir d'être belle", ou que, pelo menos, tem o direito de defender-se das ingratidões da natureza; se aceitarmos que lhe é lícito procurar os artifícios correntes e normais de aformoseamento, apelando para profissionais que o poder público autoriza, somos forçados a reconhecer a legitimidade de leis que a protejam contra a negligência, a imperícia, a imprudência de "técnicos" feitos de improviso, ou que trabalhem sem a devida cautela.

10. - Todavia, é igualmente indispensável que a culpa, em cada caso, fique bem caracterizada. Ao jurista caberá analisar e ponderar as circunstâncias do fato, afim de que não recáia culpa em quem diligentemente empregou todas as regras, tomou todas as precauções impostas pela arte. Demais, nos acidentes deste gênero, condições pessoais da vítima têm influido para a efetivação do evento: uso de tinta decomponível pelo calor, produzindo manchas; idiosincrasia em relação à substância empregada na "ondulação", etc. Note-se, a propósito, com Costa E Silva (Código Penal, I, 147) "que as legislações de nosso tempo só castigam a culpa em reduzido número de casos", pois “o sentimento natural que o fato méramente culposo desperta em quem o pratica, e a indenização das perdas e interêsses, constituem muitas vezes meios suficientes de reação e defesa"

11. - Estará o dano em aprêço incluido no art. 1.538 do Código Civil? Exige êste que a lesão consista em "ferimento ou outra ofensa à saude", e que haja "despesas do tratamento e lucros cessantes" "Ferimento", aqui, não se 
poderá entender no sentido restrito (e mais adequado) de solução de continuidade dos tecidos, por ação mecânica; e sim com a significação genérica de "qualquer alteração nos órgãos, produzida por uma violência exterior" (CASPER). Uma queimadura é, em francês, uma "blessure" (Тногот), e deve, na linguagem do art. 1.538 do nosso Código, incluir-se entre os "ferimentos" Todavia, não há "tratamento", pois a Medicina desconhece processos artificiais efetivos para estimular o crescimento dos cabelos. De sorte que a lesão só se enquadrará na hipótese do artigo, se ocorrer cessação de lucros.

12. Tratando-se de lesão transitória, não podemos considerá-la nem "aleijão ou deformidade" (parágrafo único do art. 1.538), nem “defeito” (art. 1.539).

13. A perda definitiva dos cabelos, em acidente do trabalho, é prevista por Ollive e MeIGneN : perda que "não prejudica por si mesma o trabalho, mas - especialmente na mulher - póde tornar dificeis muitas profissões" Por isso (concluem os referidos autores) "merece ser indenizada" Igual direito assiste, sem dúvida (acrescentamos nós), ao operário que, por ausência transitória dos cabelos, fique temporariamente impedido de trabalhar, ou com a sua capacidade de ganho reduzida.

14. Quer se trate, pois, de fato criminal, quer de acidente do trabalho, há para a mulher, na destruição de grande parte dos cabelos (embora sem ofensa ao couro cabeludo e mesmo com efeito transitório), uma lesão corporal, da classe das que as nossas leis prevêm Em relação à lei civil, ocorre um "ferimento", capaz ou não (segundo a situação pessoal da vítima), de determinar cessação de lucros. 